\title{
Protests challenge INSERM decision on Benveniste lab
}

Paris. Twelve prominent French intellectuals last week publicly protested at the decision of France's biomedical research organization (INSERM) to close the laboratory of Jacques Benveniste, the researcher who claims to have shown that extreme dilutions of an antibody solution can retain biological activity.

In a letter to the newspaper Le Monde, the protestors, defending the respect traditionally given to l'idée among the French intelligensia, claim that INSERM has discriminated against Benveniste because of his "heretical" ideas. They say that they do not want to enter the "scientific debate", but are keen to defend "freedom of thought" against dogma and the "deification of reason until it becomes folly".

In reply, INSERM says it used routine procedures in reaching its decision not to continue its support of Benveniste's laboratory. Under the organization's rules, a research director must reapply every 12 years to secure the continued existence of his laboratory. But INSERM says Benveniste's laboratory did not even meet the minimum criteria for being re-evaluated, as it failed to meet the requirement that each laboratory have either at least four researchers -- including two from INSERM - or else three INSERM researchers.

Benveniste claims he was unable to meet this requirement because INSERM had prevented researchers from joining his laboratory. In particular, he says that INSERM's scientific council recommended against providing a studentship to a young researcher Yolène Thomas last year, on the grounds that his research on the effects of molecules at high dilution "had not been confirmed".

But Claude Amiel, the president of the council, denies that the council tried to prevent Thomas or anyone else joining Benveniste's laboratory.

Benveniste also claims that three of his former students were appointed to research posts by INSERM - but in other laboratories. Only one of these, however, applied to Benveniste's laboratory, and after a first unsuccessful attempt, he was then given a post in another laboratory. The other two students applied directly to work in laboratories other than Benveniste's.

Amiel says that he is sympathetic to the claim that Benveniste's research "could be true". But he adds that, even if the results cannot yet be explained, they should at least be confirmed by others.

Amiel also points out that Benveniste's laboratory will not be closed until June 1995 , and that the researchers in the laboratory "still have over one year to prove their theory".

Declan Butler

\section{Top 'research' universities increase their funding lead}

London. Further evidence of the gradual emergence of élite 'research universities' in Britain was provided by the announcement last week of the budget allocations by the Higher Education Funding Council for England (HEFCE) for the year 1994-95. (The funding councils for Scotland and Wales allocate money to universities separately.)

In an overall settlement which provides English universities with an average of 4.5 per cent more than they received in the current financial year, the council says it has managed to maintain research funding virtually level in real terms.

A total of $£ 626$ million is being provided for research, out of a total budget of $£ 2.61$ billion. This is a four per cent increase on last year and, says the council, is in line with the anticipated rise in the retail price index.

But the Committee of Vice Chancellors and Principals (CVCP) is less optimistic; it argues that inflation in research costs calculated from the university pay and prices index — will be between seven and eight per cent. "Our view is that the inflation forecast is optimistic," says Ted Nield, spokesman for the CVCP.

A statement issued by the CVCP expressed its "disappointment" at the final settlement. "The absence of any real-terms increase does not live up to expectations generated by the recent white paper on science and technology," it said.

The bulk of the $£ 626$ million spent on university research by the Department for Education will, as in the past, go to the socalled 'old' universities (in contrast to the 'new' universities, recently upgraded from polytechnics or technical colleges).

Some of the best established are those receiving the greatest increase in research funds as a result of their strong performance in a research assessment exercise carried out

\section{Decline halted in UK on R\&D spending}

London. The sharp decline in Britain's spending on research and development at the beginning of the 1990 s seems to have halted, according to figures released this week by the Central Statistical Office (CSO).

The figures show that, in real terms, expenditure on R\&D stayed almost constant between 1991 and 1992, with a decrease in government funding being almost exactly matched by an increase in spending by the private sector. This was in contrast to a five per cent drop in real terms experienced between 1990 and 1991.

The CSO figures also show that, as in previous years, the most rapid increase in R\&D funding has come from private non-profit by the HEFCE, the results of which were published last May (see Nature 362, 4; 1993).

The current financial year is the first in which research funding through the HEFCE was calculated on the basis of these research assessments. It also led to 19 universities with excellent research assessments being "capped", and the money released in this way being redistributed to those who would otherwise have suffered a major decline in income because of their poor performance. For the next financial year, however, only two universities - Oxford and Cambridge - have been capped.

One result of the HEFCE's funding formula is that some of the biggest increases have gone to universities with the strongest research traditions, in particular Oxford, Cambridge and University College London. "There has always been a top ten or twelve universities who have always received most of the money for research, although it may be a bit more transparent now," says Nield.

But those universities that have been capped complain that, without such a redistribution, they would have done even better. "We are unhappy that the research cap is still in place," says Joanna Womack, the finance director of the University of Cambridge. "It has the effect that we lose $£ 3.1$ million which we would have received."

The HEFCE hopes that this will be the last year that capping will be needed. Indeed Derek Roberts, the provost of University College London, which was capped last year but has escaped this year, says that the HEFCE should go further and increase the differential between universities so that it provides even more research money to those at the top end of the assessment scale.

Fiona Gammie

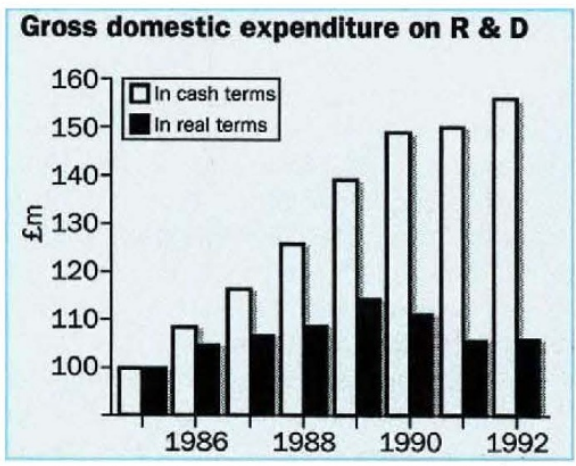

organizations - mainly research charities whose support grew by almost 10 per cent in real terms in 1992 to $£ 376$ million. 